Scholedge International Journal of Multidisciplinary \& Allied Studies

ISSN 2394-336X, Vol.04, Issue 11 (2017)

Pg 103-107.

DOI: 10.19085/journal.sijmas041101
Published by: Scholedge Publishing

www.theSCHOLEDGE.org

Email: editorial@thescholedge.org

(O) Publisher

\title{
AN EVALUATION OF MYSTICISM IN RABINDRANATH TAGORE'S GITANJALI (1910)
}

\author{
Rakib Farooq Matta \\ Barkatullah University, Bhopal, India \\ Morve Roshan K. \\ Central University of Gujarat \\ Gandhinagar, Gujarat, India
}

\begin{abstract}
Mysticism is "a constellation of distinctive practices, discourses, texts, institutions, traditions, and experiences aimed at human transformation, variously defined in different traditions". Mysticism categorically lacks an authority and anything and everything that is related to God is put under the term mysticism. An analysis of words and ideas reveals that it is the love for "nature" and "God" that made Tagore enters the realm of mysticism. However, his mystical experiences are quite different from those of the experiences of enlightened saints of India. Saints' mysticism is a result of the union achieved through deep meditation, but in Tagore's case it is only love and desire for the union. As a result of this, his Gitanjali can be considered as "Nature Mysticism" rather than Soul or God Mysticism only which enlightened saints and poets like Kalidasa or Auribindo can achieve.
\end{abstract}

KEYWORDS: Mysticism; mystic; nature; Tagore; spirituality; music; offerings

\section{Introduction}

Rabindranath Tagore is to know the essence of Indian artistic traditions, to understand a great man who becomes a "cultural hero" and "an international figure." This research paper focuses on Gitanjali which is classified under mystic poetry. The endeavor here is to look for the mystical elements in Gitanjali and how it qualifies to be a mystical poetry. Tagore is an unofficial ambassador to the world and he put India on the literary map of the world. To appreciate him fully, it is essential to note the quality and beauty of his mastery of English language that made him a renowned writer. He belonged to the whole world being "a darling of versatility". He is a poet who first gained for modern India a place on the world literary scene.

\section{Gitanjali}

Gitanjali is a collection of poems by the Indian poet Rabindranath Tagore. The original Bengali collection of 157 poems published on 14 August 1910. The English Gitanjali or Song Offerings is a collection of 103 English poems of Tagore's own English translations of his Bengali poems first published in November 1912 by the India Society of London. However, it contains translations of 53 poems from the original Bengali Gitanjali, as well as 50 other poems which are from his drama Achalayatan and eight other books of poetry - mainly Gitimalya (17 poems), Naivedya (15 poems) and Kheya (11 poems).

The translations have been often radical, leaving out or altering large chunks of the poem and in one instance fusing two separate poems (song 95, which unifies songs 89, 90 of Naivedya). The translations were undertaken prior to a visit to England in 1912, where the poems were extremely well received. In 1913, Tagore became the first nonEuropean to win the Nobel Prize for Literature, largely for the English Gitanjali. 
The English Gitanjali became very famous in the West, and was widely translated. The word 'gitanjali' is composed from "git," song, and "anjali," offering, and thus means - "An offering of songs;" but the word for offering, 'anjali', has a strong devotional connotation, so the title may also be interpreted as "prayer offering of song."

Gitanjali gives him worldwide recognition. It is appreciated for its creativity by W. B. Yeats, Ezra Pound and many other European critics. The songs in Gitanjali are the Poet's meditation on God, Man and Nature. This work Gitanjali expresses his keen sense of observation, his lively curiosity, his humour, humanity, his Philosophies of love, life and God. W.B. Yeats writes in his introduction to Gitanjali:

Rabindranath Tagore, like Chaucer's forerunners, writes music for his words, and one understands at every moment that he is so abundant, so spontaneous, so daring in his passion, so full of surprise, because he is doing something which has never seemed strange, unnatural, or in need of defense. These verses will not lie in little well-printed books upon ladies' tables, who turn the pages with indolent hands that they may sigh over a life without meaning, which is yet all they can know of life, or be carried by students at the university to be laid aside when the work of life begins, but as the generations pass, travellers will hum them on the highway and men rowing upon rivers. Lovers, while they await one another, shall find, in murmuring them, this love of God magic gulf wherein their own more bitter passion may bathe and renew its youth. At every moment the heart of this poet flows outward to these without derogation or condescension, for it has known that they will understand; and it has filled itself with the circumstance of their lives ...

\section{Rabindranath Tagore's Mysticism-Introduction}

Gitanjali thrives on Hindu mysticism and presents complex of thoughts. Tagore tries to establish an inseparable link between individual soul and greater soul. His mediations on 'God,' man' and 'nature,' in the Gitanjali, not only echo the Vedantic awareness of the Absolute but also transmit the fervor of a Vaishnavabhakta's love for God. K R Srinivasa Iyengar points out that "The Gitanjali songs are mainly poems of bhakti in the great Indian tradition ... The current coin of India's devotional poetry is melted and minted anew by Rabindranathan, but the pure gold shines as brightly as ever, even though the inscription on the coin is in English. The imagery, the conceits, the basic experience, the longing, the trial, the promise, the realization - all have the quaintly unique Indian flavor and taste."

Gitanjali represents the journey from finite to infinite. The songs in Gitanjali embrace the whole gamut of tender human feelings - love, humility, detachment, devotion, affection, dejection, and gratitude. WB Yeats believed that in these songs "A whole people, a whole civilization, immeasurably strange to us, seems to have been taken up into this imagination ..."

\section{Mysticism as a Spiritual Source}

In his journal Mysticism in Rabindranath Tagore's Gitanjali, Avinash Moharil writes:

Rabindranath Tagore hailed by Mahatma Gandhi as "The Great Sentinel” was one of those versatile men of his age, who touch and embellished modern Indian life at several points. Poet, dramatist, novelist, short story writer, composer, painter, thinker, educationalist, nationalist, internationalist such were the various roles that Tagore played with uniform distinction during his long and fruitful career. The semi mystical experience in the life of Tagore at the age of 21, where stood watching the sunrise," All of a sudden a covering seemed to fall away from my eyes and I found the world bathed in a wonderful radian with waves of beauty and joy swelling on every side, " perhaps must have provided the key to Tagore's major poetry in which mysticism was one of the most prominent features.

Mysticism represents the spiritual side of the 'human mind' and the 'human personality.' Man surely has something of Satan in him, but man has at the same time, something truly angelic and divine in him. There have been persons in whom the spiritual element is dominated who are called mystics. A mystic believes himself to be capable of seeing God or at least establishing of closed relationship with God, a relationship with enables him to have visions of God or to catch glimpses of the Divine spirit. A mystic sees God within himself in the form of light or some kind of illumination but at the same time he also sees a God or the Divine spirit and more particularly in the various 
objects of nature, in the various phenomena of Nature and in the various processes of Nature. Mysticism is a spiritual force which has always done enormous good to mankind, mystics have preserved the spiritual heritage of mankind through the ages, and among them the name of Rabindranath Tagore occupies an honorable portion. Tagore's mysticism is to be found pre-eminently in his Gitanjali.

\section{Mysticism in Gitanjali}

Gitanjali is a great mystical work and its mysticism always endures. Tagore expresses his firm convictions about God, about the human soul, and about the ultimate goal of human soul. This book is free from all kinds of material considerations and worldly desires or ambitions. Tagore seeking a communion with God and feeling sure that he would succeed in his aspiration. The mystical life is a contemplative life and it is a life in which the individual shows a complete detachment from all worldly concerns and worldly pursuits. A mystic need not renounce the world together but an attitude of detachment is absolutely necessary. There is the condition for the appreciation of Tagore's mysticism in Gitanjali. All the elements of mysticism are to be found in the poems of Gitanjali. Indeed, Gitanjali is steeped in mysticism though really in order to appreciate its mysticism we must set aside our worldly concerns and materialistic preoccupations. The very opening of the poem shows Tagore as a mystic. Here Tagore asserts the immortality of the human soul even though the human body is mortal: "Thou has made me endless, / Such is Thy pleasure" (Gitanjali, The Little Flute).

In the III poem, Tagore says to God, "The light of thy music illumines the world, / My heart longs to join in Thy song." (Gitanjali, Music of Life).

Tagore adds that God's Music has made a captive of his heart. In the next poem Tagore, as a mystic acknowledges the need of purity in life and in one's conduct and it is this realization which makes his promise to God that he would always try to keep his body pure, to keep all untruths out of his thought and to drive away all the evils from his heart. As the poem follows, Tagore expresses a strong desire for God's company. He says to God: "Now, it is time, to sit quite./ Face to face with thee" (Gitanjali,5).

In Gitanjali Tagore's longing for communion with God proves mysticism in the poem. Writing the poem after poem Tagore looks forward to meet God, to stand before God or to have a spiritual communion with God. There are many poems in which he expresses this longing, this hope and even this conviction. For instance, in one poem Tagore asks if the time has come when he may see God's Love and offer to him his silent salutation. In the next poem, Tagore says: "I am on the waiting for love to give myself up at /last into his hands: (Gitanjali, 17)

In the next poem Tagore says to God: "If thou showest me not thy face. /I know not how I am to pass / These long, rainy houses." (Gitanjali, 18)

In the poem which follows, Tagore says in the moving words to God: "If thou speakest not, I will feel. I My heart with my silence and endure it." (Gitanjali, 19)

In other poem, Tagore discovers that a perfect sweetness has blossomed in the depth of his heart. This sweetness has undoubtedly been caused by God's proximity to him. In other words, here Tagore emphasizes the divinity within him. Tagore expresses his certainty that God loves him, and so he says that even if he does not call God in his prayers and even if he does not keep God in heart, God's love would still wait for his love. Tagore says that God has been coming nearer and nearer to him ever since the beginning. All those utterances are the utterances of a mystic. Further, Tagore says that he wants God to appear before his eyes or the first of all the lights and all the forms. This shows his beginning for a visit from God. Tagore says to God: "Thus it is that Thy joy in me is so full" (Gitanjali, 56)

And he further says that because of God's love for him, he has lost himself in his love for God, so a perfect union between them has taken place. It has shown that Tagore's heart overflows with mystic fervor internally (Mysticism in Rabindranath Tagore's Gitanjali, AvinashMoharil).

Tagore has always stood for harmony, synthesis and reconciliation. Hence the combination of mysticism and humanism in Gitanjali would, then, no longer, baffle the critics. He writes in The Religion of Man, 11:"The idea of the humanity of our God, or the divinity of Man the Eternal, is the main subject of the book." 
Some mystics are ambiguous about the nature of God. This mystic dilemma is also found in Gitanjali. Sarvepalli Radhakrishnan writes in his book The Philosophy of Rabindranath Tagore (1918) about this ambiguity:

Critics may urge that the Vedanta philosophy is ambiguous about the nature of God. True it says, God is All, but it also says God is nothing. "It is not this, not this." This dilemma of mysticism which makes God sometimes the All, sometimes nothing, is not peculiar to the Vedanta writing, but runs through all mystic literature. Rabindranath's poems are full of it. In some pages the Absolute is an abstract, formless, featureless unity, not a God who deserves to be adored and worshipped. It is "the inscrutable without name and form."

It is a miracle in the sense that Rabindranath is not a religious person in the ordinary sense. He is one of the most progressive thinkers - untraditional, unorthodox - but his greatness consists in his childlike innocence. Because of that innocence, perhaps he is able to become the vehicle of the universal spirit, in the same way as the Upanishads of old times.

He is a poet of the highest category, and also a mystic. Such a combination has happened only once or twice before - in Kahlil Gibran, in Friedrich Nietzsche, and in Rabindranath Tagore. With these three persons, the whole category is finished. In the long history of man, it is extraordinary.... There have been great poets and there have been great mystics. There have been great poets with a little mysticism in them, and there have been great mystics who have expressed themselves in poetry - but their poetry is not great.Tagore is both, a great poet and a great mystic as well.

Tagore's poems from Gitanjali are offerings the songs to God. He used to say, "I have nothing else to offer. I am just as poor as a bird, or as rich as a bird. I can sing a song every morning fresh and new, in gratefulness. That is my prayer."

He never went to any temple, he never prayed in the traditional ritual way. He born as a Hindu, but it would not be right to confine him to a certain section of humanity, he was so universal. He was told many times, "Your words are so fragrant with religion, so radiant with spirituality, so alive with the unknown that even those who do not believe in anything more than matter become affected, are touched. But you never go to the temple, you never read the scriptures." His answer is immensely important for you. He said, "I never read the scriptures; in fact I avoid them, because I have my own experience of the divine, and I don't want others' words to be mixed with my original, authentic, individual experience. I want to offer God exactly what is my heartbeat. Others may have known certainly, others have known - but their knowledge cannot be my knowledge. Only my experience can satisfy me, can fulfill my search, and can give me trust in existence. I don't want to be a believer."

These are the words to be remembered: "I don't want to be a believer; I want to be a knower. I don't want to be knowledgeable; I want to be innocent enough so that existence reveals its mysteries to me. I don't want to be worshiped as a saint." And the fact is that in this whole century, there was nobody else more saintly than Rabindranath Tagore - but he refused to be recognized as a saint.

He said, "I have only one desire - to be remembered as a singer of songs, as a dancer, as a poet who has offered all his potential, all his flowers of being, to the unknown divineness of existence. I don't want to be worshiped; I consider it a humiliation... ugly, inhuman, and removed from the world completely. Every man contains God; every cloud, every tree, every ocean is full of godliness, so who is to worship whom?"

"Rabindranath Tagore's philosophical and spiritual thoughts transcend all limits of language, culture, and nationality. In his writings, the poet and mystic takes us on a spiritual quest and gives us a glimpse of the infinite in the midst of the finite, unity at the heart of all diversity, and the Divine in all beings and things of the universe."

- From the Preface by Swami Adiswarananda 


\section{Mysticism in the Worship of Nature}

Tagore finds the presence of God in the nature around him. He addresses God by admiring the beauty of nature which is the reflection of the presence of God himself. Tagore is not a self centered person. At the time of hardships and complaints he does not forget the blessings showered by God. Direct references are given in the poems wherein he says to God that He gifts man things unasked. Those things which man enjoys in this universe, for example, the elements of the nature like sky, stars, wind, flowers etc. are the greatest gifts man can ever have. But still Tagore says that, "My desires are many and my cry is pitiful" (p.24). He is in such a desperate mood to be with him that he says, "O thou holy one, thou wakeful, come with thy light and thy thunder" (p.38). Here, it seems that Tagore conveys to the reader that thunder and lightning shows the power and vibrations in the universe when God reveals himself to his creations. To his surprise, he receives a gift from God, a 'sword' (p.49, 50), which he finds very difficult to relate to. Later, his creative power enables him to understand that it is the pain with which he needs to cut off all his desires from the mind and body. The sword can be treated as fire in Buddhist philosophy to burn out the unwanted and unending passions. In the same poem, he uses the images of flower, spices and vase of perfumed water to symbolize materiality in life. As the poem develops, 'sword' takes greater manifestations in the poet's creative realm. He writes, "Thy sword with its curve of lightning like the outspread wings of the divine bird of Vishnu" (p.50). Thinking from the perspective of spirituality, one can understand that 'sword' is being referred to as a weapon against materiality. The sword is compared to the divine bird 'Garuda' of Lord Vishnu. Garuda is the enemy of snakes. Snake, in one of its symbolizations, represents sexuality in Hindu Philosophy and Garuda, spirituality being divine. Thus the interpretation becomes clear here. The poet continues his address to God as golden light upon the leaves, idle clouds, passing breeze, spotless and serene, maya (illusion), father etc (p.54). But what confuses one is the way in which he uses the same image to symbolize multiple ideas. For example, "Clouds made of tears and sighs and songs" (p.61) symbolizes his sacrifices to attain the ultimate union. So the image "cloud' takes two dimensions here. It seems, as any mystic, he attains the union that he is longing for, at the end of his address and this can be well refined from the lines, "unknown man plays upon his lute" (p.65), "In memory I woke up and found my garden full with wonders of flowers" (p.70). Tagore uses the metaphor of "little flower" (p.20) to state that every man is like a flower waiting for the opportunity to attain salvation by decorating His feet, neck or head.

\section{Conclusion}

To conclude, it finds that Tagore's Gitanjali is a mystical, yet there is a difference that distinguishes it from the Western Mysticism. Gitanjali is not a sign of pain but an abundance of cheerfulness. Tagore's mysticism does not sprout from solitary asceticism but from the resourceful life in this world of man and animals.It is this humanism that makes Gitanjali unique. Indeed 'Mysticism' is over-filled in Gitanjali. It is a great feature in Gitanjali which makes it unique in all Indo -Anglican literature.

\section{References}

[1] Avinash Moharil: Mysticism in Rabindranath Tagore's Gitanjali, International Referred Research Journal, January, 2012. ISSN: $0974-2832$.

[2] B.C. Chakraborty: Rabindranath Tagore: His Mind and Art (New Delhi: Young India Publications, 1971).

[3] Ghosh, Sisir Kumar: Rabindranath Tagore, New Delhi, Sahitya Akademi, 1990.

[4] Gitanjali: Spiritual Poems of Rabindranath Tagore - An e-book presentation by The Spiritual Bee;www.spiritualbee.com

[5] International Journal of Innovative Research and Development, ISSN: 2278 - 0211.

[6] Mohit Ray: Tagore's poems, Part I, Atlantic, 2007.

[7] Preface by Swami Adiswarananda: Tagore, The Mystic Poets

[8] Rabindranath Tagore. Gitanjali (Macmillan, Madras) 199

[9] S.K. Paul: The complete poems of Rabindranath Tagore's Gitanjali; Text and Critical Evaluation.

[10] Rabindranath Tagore: The Religion of Man: Being The Hibbert Lectures for 1930 (New York, The Macmillan Company, 1913).

[11] N V, R. (2015). Mysticism in Tagore's Gitanjali. Scholedge International Journal of Multidisciplinary \& Allied Studies ISSN 2394-336X, 2(2), 6-12.

[12] The Philosophy of Rabindranath Tagore, Macmillan and Co., Limited, 1919. 